University of East London Institutional Repository: http://roar.uel.ac.uk

This paper is made available online in accordance with publisher policies. Please scroll down to view the document itself. Please refer to the repository record for this item and our policy information available from the repository home page for further information.

To see the final version of this paper please visit the publisher's website.

Access to the published version may require a subscription.

Author(s): Taylor, Barbara.

Article title: Feminists Versus Gallants: Manners and Morals in Enlightenment Britain

Year of publication: 2004

Citation: Taylor, B. (2004) 'Feminists Versus Gallants: Manners and Morals in Enlightenment Britain' Representations 87 Summer 2004, pp.125-148

Link to published version: http://dx.doi.org/10.1525/rep.2004.87.1.125

DOI: 10.1525/rep.2004.87.1.125 


\title{
Feminists Versus Gallants: Manners and Morals in Enlightenment Britain
}

The male sex among a polite people, discover their authority in more generous, though not a less evident manner; by civility, by respect, and in a word by gallantry.

-David Hume, "Of the Rise and Progress of the Arts and Sciences," $1742^{1}$

\begin{abstract}
Many of the sentiments [in A Vindication of the Rights of Woman] are undoubtedly of a rather masculine description. The spirited and decisive way in which the author explodes the system of gallantry, and the species of homage with which the sex is usually treated, shocked the majority.

-William Godwin, Memoirs of the Author of a Vindication of the Rights of Woman, $1798^{2}$
\end{abstract}

\begin{abstract}
Mary Wollstonegraft's status as an Enlightenment philosophe earns her divided notices. For admirers of Enlightenment, Wollstonecraft's identification with what she described, significantly, as the "masculine and improved sentiments of an enlightened philosophy" wins her kudos. ${ }^{3}$ By contrast, those who condemn Enlightenment as sectarian - a "conspiracy of dead white men in periwigs to provide the intellectual foundation for Western imperialism," in Eric Hobsbawm's satiric formulation - criticize her complicity in it. ${ }^{4}$ The judgments, until recently, have been more polemical than substantively historical, with little detailed attention to Wollstonecraft's place in the constellation of writers, ideas, and intellectual practices retrospectively labeled Enlightenment. ${ }^{5}$ Probably for this reason, both sides in the argument tend to exaggerate her Enlightenment allegiances and to underestimate the complexities of her intellectual position. Far from an uncritical spokeswoman for a monolithic "Enlightenment," Wollstonecraft elaborated her philosophical stance against the grain of mainstream enlightened opinion. This was particularly true of her major feminist work, A Vindication of the Rights of Woman (1792) where, far from echoing Enlightenment perspectives, she mounted
\end{abstract}

\footnotetext{
AB S TRAC T Mary Wollstonecraft is usually portrayed as an Enlightenment thinker. But in A Vindication of the Rights of Woman (1792) she denounced "modern philosophers" for purveying prejudicial images of women masked in a rhetoric of sexual compliment. This essay explores the relationship between Enlightenment attitudes to women and feminism in Britain, showing the gap that opened up between mainstream enlightened opinion ("modern gallantry") and women's-rights egalitarianism in the 1790s. / REPRESENtations 87. Summer 2004 (C) The Regents of the University of California. is s N 0734-6018, electronic I S s N 1533-855X, pages 125-48. All rights reserved. Direct requests for permission to photocopy or reproduce article content to the University of California Press at www.ucpress.edu/journals/rights.htm.
} 
a systematic assault on "modern" writings on women that, in her view, portrayed women "as a kind of subordinate beings, and not as a part of the human species." 6 If the Rights of Woman is a work of Enlightenment philosophy, in other words, it is one that highlights important tensions in Enlightenment thought, particularly in enlightened thinking on gender issues. ${ }^{7}$

As a democratic utopian dedicated, as her friend Mary Hays put it, to "guiding, enlightening, and leading the human race onward to felicity," Wollstonecraft had a strong sense of radical-philosophical pedigree. ${ }^{8}$ Her two Vindications are crammed with enlightened borrowings - from Francis Bacon, John Locke, Adam Smith, Voltaire, Gottfried Wilhelm Leibniz, Georges-Louis Buffon, Hume, Lord Monboddo, Francis Hutcheson, Immanuel Kant, Joseph Priestley, Richard Price, and, above all, Jean-Jacques Rousseau, whose influence permeated her thought from 1788 on. Her Historical and Moral View of the French Revolution (1794) — written in terrorist France and clandestinely shipped to her London publisher chapter-by-chapterinterwove a detailed chronicle of the early stages of the revolution with a triumphalist account of Enlightenment's advance across Europe and America. Tracing an intellectual trajectory from Locke to Comte de Mirabeau, Wollstonecraft showed how the "bright lines of philosophical truth" purveyed by "men of genius of the last and present ages" — natural jurists, physiocratic economists, encyclopedists - had penetrated and dispelled the moral darkness of despotism

till now arrived at the point when sincerity of principles seems to be hastening the overthrow of the tremendous empire of superstition and hypocrisy, erected upon the ruins of gothic brutality and ignorance. ${ }^{9}$

Elsewhere, however, a more critical note was sounded. "Enlightened philosophers" who "talk most vehemently of the native rights of men" were often less democratic in practice, she claimed in 1790 in A Vindication of the Rights of Men. "They bow down to rank and are careful to secure property; for virtue, without this adventitious drapery, is seldom very respectable in their eyes - nor are they very quicksighted to discern real dignity of character when no sounding name exalts the man above his elbows." 10 Two years later, in $A$ Vindication of the Rights of Woman, it was these philosophes' old-world attitudes to women that earned her wrath: a theme dramatized in her final novel, The Wrong of Woman, or Maria, where various men of "philosophical disposition" are depicted expatiating on "the evils which arise in society from despotism of rank and riches" while treating the women around them with cruelty or indifference. " "I may be accused of arrogance," Wollstonecraft wrote in the Rights of Woman, "still I must declare what I firmly believe, that all the writers who have written on the subject of female education and manners from Rousseau to Dr Gregory, have contributed to ... degrade one half of the human species, and render women pleasing at the expense of every solid virtue."12

Wollstonecraft's criticism of her contemporaries' attitudes to women usually focuses on her quarrel with Rousseau - and with good reason. No late-eighteenth- 
century champion of sexual equality could avoid tackling Rousseau; certainly not a fellow philosophe like Wollstonecraft, whose point-by-point refutation of the notorious book five of Emile, "Sophie, or the Woman," was the most systematic and influential of the period. But even as she excoriated Rousseau for his "partial," "crude" views on women, Wollstonecraft showed herself to be as much disciple as detractor, drawing heavily on his critical-utopian philosophy for her own radical perspectives. No such subtle play of influence and antagonism was detectable, however, in her assault on influential works on women emanating from the British Enlightenment, whose "baneful effect on the morals and manners of the female world" she roundly condemned. ${ }^{13}$ The element in these works that earned her fiercest criticism was their "gallantry," meaning their sentimental homage to the "fair sex" which had so "bubbled" women's minds, she complained, that they aimed only "to inspire love, when they ought to cherish a nobler ambition, and by their abilities and virtues exact respect." 14 The writers foremost in her sights here were Dr. John Gregory-Scottish Enlightenment medical man and author of the best-selling $A$ Father's Legacy to His Daughters - and Reverend James Fordyce, another Scottish enlightener and author of several hugely popular works of advice to women, with various other like-minded oracles, male and female, rebuked along the way. "If women be ever allowed to walk without leading-strings, why must they be cajoled into virtue by artful flattery and sexual compliments?" she demanded after quoting at her readers a particularly smarmy passage from Fordyce's Sermons to Young Women: "Speak to them the language of truth and soberness, and away with the lullaby strains of condescending endearment!"'15

This essay explores Wollstonecraft's relationship to Enlightenment via her critique of enlightened ("modern") British gallantry. Modernist exponents of gallantry advanced their case through a wide range of genres: moral philosophy, educational treatises, history, sermons, novels, poetry, as well as conduct books like those of Fordyce and Gregory. Advice manuals like Fordyce's and Gregory's are not usually read as Enlightenment texts, but in fact such writings were a key route by which new moral-philosophical discourses reached general audiences. ${ }^{16}$ Ideas originating as high-philosophical interventions were reworked - often, as in Fordyce's case, by clergymen - into didactic recipes for feminine morals and manners. Elsewhere I have discussed the prowomen current within British Protestantism that, flowing into eighteenth-century writings on women, lent them a distinctly femalechauvinist flavor, which in some cases was not just rhetorical: ${ }^{17}$ John Gregory was publicly ridiculed on one occasion for his feminine biases. ${ }^{18}$ Placing the Rights of Woman alongside these works, the points of resemblance are striking, which no doubt partly explains why Wollstonecraft's attack on them was so vitriolic. In-house quarrels - as this contest between Enlightenment gallants and feminists definitely was-are often the fiercest.

Wollstonecraft's first shot at gallantry was fired at Edmund Burke in 1790 when, replying to his Reflections on the Revolution in France (1790), she ridiculed his 
enthusiasm for French chivalry, that "homage to [women] in general" which he championed as the apex of cultured civility, in defiance of ill-bred revolutionaries' dismissal of it as mere "romance and folly." ${ }^{19}$ Romance and folly "indeed" was Wollstonecraft's retort,

because such homage vitiates [women], prevents their endeavouring to obtain solid personal merit; and in short, makes those beings vain inconsiderate dolls, who ought to be prudent mothers and useful members of society. ${ }^{20}$

Chivalric reverence for women was an Old Regime fatuity that, like all aristocratic follies, belonged in the dustbin of history. The Rights of Woman took up this theme, attacking Louis XIV for having introduced into French society the "princelike" adulation of women that, spreading throughout Europe, had proved "fatal to reason and virtue." "Yet this heartless attention to the sex is reckoned so manly, so polite," Wollstonecraft wrote despondently, "that, till society is very differently organised, I fear, this vestige of gothic manners will not be done away.",21

Deriding gallantry as a courtly archaism was good polemics, given the antielitist biases of most of Wollstonecraft's readership. Tackling middle-class proponents of gallantry, Wollstonecraft scorned them as vulgar arrivistes aping elite manners, and there was certainly some truth to this. But the constellation of ideas described as "gallant" by eighteenth-century British writers, while owing much to elite etiquette traditions, was not in itself a "gothic" residue but an innovation linked to the development of middle-class intellectual culture. The enlightened gallants criticized in the Rights of Woman were not sexual dinosaurs but literary New Men seeking fresh grounds for masculine authority. As one leading historian of Scottish Enlightenment has written of James Fordyce, he did not "merely reinforce a patriarchal structure which he found already existing in British society, but ... helped to lay an entirely new foundation for male superiority." ${ }^{22}$ This innovative element in enlightened gallantry was not acknowledged, possibly not recognized, by Wollstonecraft, yet she struck hard at its most vulnerable points, of which there were plenty. For as a defence of male supremacy, gallantry was about as leaky as a notion can get and still remain afloat. Only fierce determination born of anxiety could prevent it from capsizing. Yet at the time Wollstonecraft took it on, it was fast becoming middle-class orthodoxy: a salient reminder (contra Enlightenment optimism) of the small role that truth plays in the fate of most ideas.

The roots of enlightened British gallantry lay principally in seventeenthcentury French salon society, which was famously prowomen. ${ }^{23}$ It was women, according to the salonnier Saint-Evremond (whose translated writings did much to convey this ideal into Britain), who infused social life with the "Sweetness ... Charms and Agreements" so essential to polite conviviality; or as one earlyeighteenth-century English - probably female - enthusiast for French gallantry put it, it was female "Company and Conversation" that induced in men that "Kind- 
ness and Good Will" that was the "Perfection of Civility": "there is a tender Softness in the Frame of our Minds, as well as in the Constitution of our Bodies, which inspires Men, a sex more rugged, with the like Sentiments and Affections, and infuses gently and insensibly a Care to oblige." ${ }^{24}$

French salons, with their ethos of discursive complaisance enforced by a network of powerful hostesses, embraced this code practically as well as rhetorically. Initial British reception of the ideal, however, was more equivocal. Elite society discovered in itself a new appreciation of the feminine virtues, with ladies of fashion preening themselves on their innate elegance and refinement. Outside the beau monde, however, accusations of "French foppery" and "coxcombery" abounded. Aspirational bourgeois commentators, fearful of being accused of arriviste absurdities while straining after polite sophistication, faced a dilemma. The ambivalence displayed by Joseph Addison's Spectator, that jaunty spokespiece of all things modern, was typical. Bowing gallantly to his female readership in 1711, Addison promised them the proper "Awe and Respect" denied them elsewhere, while at the same time ridiculing the gallant as an effete rake who, endeavoring to please the ladies, becomes an aficionado of all things feminine: "He knows the History of every Mode, and can inform you from which of the French King's Wenches our Wives and Daughters had this Manner of curling their Hair." ${ }^{25}$ Writing in the same year, the eminent theorist of manners, Lord Shaftesbury, excoriated the "modern growth" of gallantry as a risible, un-English anachronism, "the mere dregs of chivalry."

At a time when this mystery of gallantry carried along with it the notion of doughty knighthood, when the fair were ... won by dint of lance and manly prowess, it was not altogether absurd ... to pay [women] homage and adoration, make them the standard of wit and manners and bring mankind under their laws. But in a country where no she-saints were worshipped by any authority from religion, it was as impertinent and senseless as it was profane to deify the sex, raise them to a capacity above what nature had allowed and treat them with a respect which, in the natural way of love, they were themselves the aptest to complain of. ${ }^{26}$

Looking back nostalgically to ancient Greece's exclusion of women from male company, Shaftesbury bewailed women's predominance in "modern conversations," which, depriving men of "masculine helps of learning and sound reason," rendered them "effeminate." "Our sense, language and style," he concluded petulantly, "should have something of that ... natural roughness by which our sex is distinguished." 27

Criticisms of this kind persisted throughout the century. Alongside them however there grew up a progallantry position that acquired increasing popularity from the 1730s. A key locus for this development was the enlightened Scottish intelligentsia, in both its "learned" and "conversible" manifestations - to use terms employed by David Hume in a series of 1740s essays celebrating the rise of modern politeness. "Conversible society," that realm of "easy and sociable" discourse among civilized men and women, was a natural site of gallantry, Hume insisted. Setting himself 
against Shaftesbury and other "zealous partisans of the ancients" who condemned gallantry as effete and ridiculous, Hume championed it as a "credit to the present age."

Nothing ... can proceed less from affectation than the passion of gallantry. It is natural in the highest degree. Art and education, in the most elegant courts, make no more alteration on it, than on all the other laudable passions. They only turn the mind more towards it; they refine it; they polish it; and give it a proper grace and expression. ${ }^{28}$

In the 1770s and ' 80 s this argument acquired a historical gloss. In a series of works documenting the beneficial impact of the civilizing process on European women, Scottish Enlightenment historians identified medieval chivalry as a decisive stage in women's transition from barbaric oppression to their current happy position as the "friends and companions of man." It was the "respect and veneration" for women characteristic of the "gothic age" that still exerted a "considerable influence upon our behaviour towards them," the Glasgow historian John Millar explained in his seminal The Origin of the Distinction of Ranks (1771). Looking back to feudal warrior society, Millar anatomized its "manifest tendency to heighten and improve the passion between the sexes":

To be in love was looked upon as one of the necessary qualifications of a knight; and he was no less ambitious of showing his constancy and fidelity to his mistress, than of displaying his military virtues. He assumed the title of her slave, or servant ... [and this] sincere and faithful passion ... was naturally productive of the utmost purity of manners, and of great respect and veneration for the female sex. ${ }^{29}$

Several centuries later, this reverence for women could still be found, albeit in soberer form, in that general respect for female "talents and accomplishments" that for Millar, as for a host of other late-eighteenth-century enlighteners, was a key index of Britain's civilized status. Savages might treat their wives as childbearing slaves, or ancient Greeks and Romans imprison them in the home, or Eastern despots exploit them sexually in their seraglios, but eighteenth-century British men, absorbing and modernizing chivalric traditions, knew how to properly appreciate their womenfolk. The message- delivered with great historical élan by Millar, Lord Kames, William Robertson, William Alexander, and many other Scottish exponents of the civilization paradigm - became a staple of writings by custodians of manners, English and Scottish alike. ${ }^{30}$ It was the "spirit of ancient chivalry," the enlightened Manchester cleric John Bennett told his female readers in 1787, that was responsible for that species of gallantry, that "moulded by increasing knowledge ... still ... pervades ... every part of the continent of Europe," elevating women's status and inducing men to view themselves as "subservient to [women's] ease and ... protection." "Th1 The cultural prestige enjoyed by eighteenth-century Englishwomen was a "Gothic extract," Lord Shaftesbury wrote on a complaining note earlier in the century: "gallantry and ladies must have a part in everything that 
passes for polite in our age." 32 Or as James Fordyce put it, more positively, it was women's "wonderful influence" over men in "ancient days" that had laid the ground for enlightened sexual attitudes: "There cannot, I am persuaded . . . be many worse symptoms of degeneracy, in an enlightened age . . . than . . . indifference about the regards of reputable women." 33

As well as introducing a relativist element into enlightened thinking about gender-power relations, historicist accounts like these served to counter doctrines of innate female character. After all, if women's way of life was amenable to historical transformation, might not their personality traits be equally susceptible to change? Might not qualities like delicacy and weakness, generally attributed to women's "original constitution," result rather from their circumstances and education, as John Millar mooted? ${ }^{34}$ The idea was not new - the Cartesian feminist François Poulain de la Barre, among others, had canvassed it a century earlier - but it gained greater weight and currency. ${ }^{35}$ Thus, according to William Alexander's popular History of Women (1779), the physical weakness of women in modern commercial societies was due to their "sedentary life, low abstemious diet, and exclusion from fresh air." Any inferiority displayed by modern women was "entirely an offspring of . . culture," Alexander insisted. ${ }^{36}$ Likewise the Scottish traveler-soldier, Alexander Jardine, who in 1788 reported the wide variety of traits displayed by women of different nations, concluded that "most of the present striking differences between the male and female character, are more the effect of art than nature." 37 Disparities of "virtue and understanding" between the sexes were mostly due to "diversity of education," another Scottish luminary, James Beattie, wrote in his Elements of Moral Science (1790-93), while a half-century earlier Hume had controversially declared that even chastity, the defining quality of feminine virtue, was a cultural artifact, a product of that "peculiar degree of shame" that society attached to female infidelity in order to ensure legitimate paternity: "and when a general rule of this kind is once established ... [it] makes us extend the notions of modesty over the whole sex." 38

None of these thinkers denied innate sexual difference tout court: "each sex . . . is fitted by the Author of nature for accomplishing different purposes." 39 But if women were designed for home life, men too, it was emphasized, were domestic creatures in whom the civilizing process had meant an enhancement of family feeling. Nor should female domesticity be understood as an unchanging fact of nature but rather as a historical phenomenon whose forms and consequences varied over time. Here the contrast between the status of married women in the GraecoRoman world and their position in eighteenth-century British society was a popular theme, migrating rapidly from philosophical-historical texts into prescriptive works. Thus, whereas in ancient Greek society, James Fordyce told his readers, "married women were in a manner secluded from society, being mostly confined to the interior apartments of their houses, and wholly engrossed by domestic occupations," to modern British minds such practices seemed "so uncourteous to the 
ladies, as well as unanimating to the men" that it was hard to imagine how they "could obtain amongst a people highly polished." ${ }^{40}$ For John Bennett, likewise, the ancient sequestration of women in the home appeared "a low and inglorious condition of servility" that made men "rough and insolent" and women "awkward and inelegant." ${ }^{\text {"41 }}$ How much better, as David Hume argued against admirers of classical patriarchy, to encourage women to leave their firesides to mingle freely with men, thereby producing in both sexes "an increase of humanity, from the very habit of conversing together, and contributing to each other's pleasure and entertainment." ${ }^{42}$

The home was women's realm, enlightened opinion-makers agreed, but so too was the world of polite sociability, for which certain traits ideally fitted them, namely love of peace, natural refinement of manner, and, most crucially, instinctive tenderness or sympathy for others - attributes inherent to all good Christians but present in women to an exceptional degree. Women, British Enlightenment thinkers all agreed, were primary bearers of the "affections," meaning not just love of family and other intimates but the "social sympathies" on which civilized progress depended, since it was through feminine influence that men, that bellicose and uncivil sex, became "softened" into social beings. After all, what "better school for manners" could there be, Hume demanded, "than the company of virtuous women":

where the mutual endeavour to please must insensibly polish the mind, where the example of female softness and modesty must communicate itself to their admirers, and where the delicacy of that sex puts every one on his guard, lest he give offence by any breach of decency? ${ }^{43}$

Hume's emphasis here on sexual modesty was a core theme of enlightened gallantry, with men urged to act as true knights by curbing licentiousness and eschewing "loose women" in favor of those "who join good breeding, and liberal sentiments, to purity of mind and manners." ${ }^{" 4}$ In stressing erotic propriety in this way, modern gallants were setting their faces against the well-established tradition of amatory gallantry still current in elite circles in the second half of the eighteenth century, as emblematized by that notorious work of paternal advice, Lord Chesterfield's Letters to his son, in which the young heir was urged to behave gallantly, that is, to engage in erotic dalliance with fashionable ladies, as part of his worldly education. Published in 1774, the Letters were an ideal foil for enlightened moralists seeking to distinguish their decorous sexual code from this dissolute, aristocratic, andabove all-French-inspired tradition (it was "the graceful and bewitching influence" of French politesse that had corrupted Chesterfield, it was widely alleged). ${ }^{45}$ Virtually every British enlightened-gallant text contrasted Gallic, lascivious gallantry to its own native code of female modesty and male self-restraint. Chaste conviviality, with "the highest subjects of morality treated of as natural . . discourse," was true British politeness, it was decreed. ${ }^{46}$ 
This was not a counsel for coldness and constraint. British enlighteners were keen on the passions, believing their energies ought not to be repressed but harnessed to the demands of modern civility, for "the more men refine upon pleasure, the less will they indulge in excesses of any kind." 47 Thus, whereas in primitive societies unrestrained mingling of the sexes had led to licentiousness, among civilized peoples, John Millar explained, "the pleasures which nature has grafted upon the love between the sexes, become the source of an elegant correspondence." ${ }^{48}$ Far from inimical to virtuous sociability, Hume similarly argued, in polite societies the "friendship and mutual sympathy" generated by erotic desire becomes a fount of social sentiment. Men are "commonly proud and selfish"; desire for women softens this egoism and arouses consideration for others, partly by stimulating a flow of natural sympathy but also through women's example, as female "complaisancy" inspires in men a similar generosity of manner. ${ }^{49}$ Male desire and women's natural civility combine to produce what David Fordyce-James Fordyce's elder brother, an Aberdeen moral philosopher - described as that "softened intercourse" characteristic of truly civilized societies. "Now I ask," David Fordyce demanded in his 1760 Dialogues Concerning Education, a classic statement of the enlightened gallant position,

what an insipid thing were human life, were it not seasoned with the elegant refinements of love and gallantry, and all those tender delicacies of conversation, which are inspired by female softness, and directed by good manners? ${ }^{50}$

Like his brother James, David Fordyce was a clerical philosophe and minor scion of Scottish Enlightenment. His Dialogues record a series of conversations held in an imaginary rural academy between "Cleora," an enlightened young woman of intellectual tastes, and a group of young male scholars. Sexual manners are a leitmotif, with the distinction between vicious and virtuous gallantry - "the wanton effusions of an indiscreet and excessive complaisance" versus "sober expressions of a genuine esteem" - analyzed in detail. "M1 "May we not be polite and agreeable without polishing ourselves out of our old British plainness and sincerity?" Cleora wants to know, or is male address to women inevitably a "conveyance of lies" designed to "flatter and impose"? Her companions respond by denouncing amatory gallantry as beau-monde venality, a "system of fraud ... to ruin the innocent," and insisting that gallant sentiment must be tempered by "rules of honour and humanity." Nor is it women's sexual allure that attracts true gallants, they claim, but rather their "moral charms." It is only rakes or men of low understanding who are "caught with mere show, and imagine that a fine complexion, or a handsome set of features, include every virtue and perfection." ${ }^{52}$

Like all enlightened-gallant works, the Dialogues carry a definite feminist charge. "Cleora," while lovely and sweet-mannered, is no shrinking violet but a self-respecting woman conscious of her dignity, telling off her young admirers when they become too flirtatious ("we shall converse more freely if we do it on equal 
terms," she instructs one particularly importunate lad), and dismissing chivalric compliments as "fine toys and Gew-gaws" intended by men "to amuse us, and when you see us taken with the shining trifles . . . carry us off in triumph and reduce under the order of domestic discipline." Yet she is no enemy to conventional femininity, believing that women's chief social duty is to "delight and polish the men," and expressing shock at women who are "forward in conversation, vain and arrogant, rough and boisterous." Women should receive a good education, she insists, but only to prepare them to be "good wives and women." She herself has been well taught, but so discreetly that no whiff of scholarship is detectable in her sentiments, which appear rather "pure dictates of nature." 53

Bookish women who flaunt their erudition are singled out for attack, as they were in most modernist writings on women. Animus against learned women, particularly those displaying their wisdom in print, was a long-standing feature of British intellectual life that few Enlightenment writers sought to challenge. Again, the nightmare scenario was France, where "female literature is swelled beyond its natural dimensions" and femmes philosophes ruled unchallenged, reducing men of letters to craven fops: a terrifying spectre of intellectual emasculation. "Women were not formed for ... literary refinement," John Bennett harangued his female readers: "The wife, the mother, and the oeconomist of a family ... [is] lost in the literary pedant; the order of nature [is] totally reversed." ${ }^{.55}$ Satirical sketches of such viragos - Cleora's evil sisters - dotted enlightened educational treatises, such as "Corinna," drawn by Vicesimus Knox in 1779, who when in "company with enlightened people"

expatiates on the happiness of possessing a philosophical turn. ... Voltaire, Rousseau, Bolingbroke, and Hume, are her oracles. She is dreaded by her own sex, and indeed voluntarily gives up their society. But the men she thinks more entertaining. ${ }^{56}$

"How forbidding an object!" James Fordyce exclaimed of such women: "Feminality is gone: Nature is transformed ... [into] a clamorous, obstinate, contentious being ... fit only to be chased from the haunts of society. ${ }^{37}{ }^{57}$ David Fordyce's Cleora endorses this sentiment, condemning out of hand "female philosophers and virtuosos." "A woman [is] in a dangerous way, who runs after the secrets of learning," she tells her young men friends, who want little convincing. ${ }^{58}$

Fordyce's Cleora is an enlightened-gallant pin-up: intelligent without being intellectual, modest but not priggish; self-respecting while remaining ever mindful of her feminine weaknesses and natural dependence on men. The courtesies her young interlocutors pay to her are a respectful tribute to her virtues but also a tactful expression of their innate superiority. For just as "superior affability" toward social inferiors is the hallmark of a true gentleman, so such "condescension ... is still more decent and necessary" with women, Fordyce counsels his male readers: "We can hardly shew them too much Respect, or pay them too much Deference, that we may conceal, and, in some degree, compensate to them the Superiority which 
Nature has given us over them." 59 Such frank endorsements of male dominance littered British Enlightenment texts. It was the "superiority vested by law in ... men" for which modern women were happily recompensed by "that superior complaisance which is paid to them by every man who aspires to elegance of manners," James Beattie explained; or as Alexander Jardine put the matter, more bluntly, "all the romantic nonsense of modern gallantry" was the polite mode by which modern men "act [ed] the tyrants over the female part of society." ${ }^{60}$ In civilized nations, it is rituals of deference rather than brute coercion with which men enforce their dominion over women: gallantry is the nonviolent expression of male ascendancy.

This principle of power-turned-polite- "contempt . . . disguised; authority concealed," in Hume's trenchant formulation — was at the heart of British Enlightenment: which is why Wollstonecraft's attack on it, as we shall see in a moment, had a significance that went beyond her feminism. ${ }^{61}$ But before turning to this, let us consider further the motives behind this new sexual politesse. Why did a renovated chivalry - and its derivatives, those mass-market panegyrics to femininity of which Wollstonecraft complained so bitterly - achieve such ascendancy among eighteenth-century British progressives? Or to put the question differently, what was the problem that enlightened gallantry designed to solve?

Modernity as conceived by British enlighteners had at its heart a character type - the polite or civilized personality — most of whose key attributes (peaceability, sensibility, sympathy, sociability) belonged on the feminine side of the gender axis. As the innately refined sex, women set the standard for cultivated humanity; their delicate responsiveness to others ("social sympathy") was the sina qua non of true civility. As Mary Catherine Moran has shown in an important essay on John Gregory, many of the behavioural diktats issued to women by enlightened advicegivers - to hide superior intellectual ability, to avoid shows of egoism, to display a tender interest in others - applied equally to civilized men: and here of course a considerable dilemma arose. ${ }^{62}$ For if men were to emulate women, what became of virility and its associated prerogatives? "As a code," Amanda Vickery has noted, "politeness was always in danger of collapsing into effeminacy": a peril loudly trumpeted by conservative moralists but widely acknowledged too by enlightened thinkers, who worried about the spread of foppery and an attendant collapse of national virility. "The delicate sensibility required in civilised nations sometimes destroys the masculine firmness of the character," Adam Smith warned. ${ }^{64}$

Discussing this feminization of modern personhood, scholars like John Pocock, Carol Kay, and Terry Eagleton have pointed to the political forces propelling it. ${ }^{65}$ In a nation still licking its wounds from decades of civil strife, gentle manners were definitely at a premium. "When the polite man of commercial and cultivated society looked back into his past," John Pocock writes, "what he saw . . . [were] passions not yet socialised"; 66 and it was as exemplars of civilized emotion, with its attendant promises of peace and stability, that British philosophes turned to women, arguing that without women's soothing influence men were "dangerous animal[s] to soci- 
ety." ${ }^{\prime 67}$ Enlightenment images of a brave new world of independent-minded, selfdetermining citizens rubbed up against still-fresh memories of sanguinary sectarianism and civil war: constant reminders of the hazards posed by unchained minds and emotions. As the sex whose survival depended on its ability to please and conciliate others, woman offered an apparent solution to this Hobbesian dilemma: an other-attuned subjectivity that became the template for a properly socialized selfhood. The self-suppression, the relentless self-policing that constituted the properly feminine ego became the hallmark of modern civility. In one sense, of course, this elevation of Woman into the paradigmatic modern subject had little to do with women or gender at all, serving rather as a metaphoric frame for the complex psychic changes required by a commercializing society. Yet the anxieties to which these changes gave rise, the fear of widespread emasculation or even a total collapse of sexual boundaries, seem to have been sharp enough - especially among men of letters. No reader of eighteenth-century male-authored cultural commentary can fail to be impressed by the reams of print devoted to the threat posed by women's actual or potential predominance in polite society, especially polite literary society. What do we make of this?

Until recently, historians of gender were agreed in depicting the eighteenth century as a time of hardening gender divisions, a period when men's and women's lives bificurated into "separate spheres." But closer examination of the evidenceby, among others, Amanda Vickery, Margaret Hunt, Linda Colley, and Olwen Hufton-shows that far from becoming more entrenched, by the second half of the century "the boundaries supposedly separating men and women were . . . unstable and becoming more so." ${ }^{.68}$ In the case of men and women of the rising middle class, I would put the argument even more strongly, and propose that the "gender panic" (to borrow Dror Wahrman's phrase) expressed by moralists during this period signaled an unprecedented cultural convergence between the sexes. ${ }^{69}$ Separatespheres propaganda notwithstanding, current scholarship indicates that by the mid-eighteenth century, men and women of the British middle ranks were becoming more like each other - in social attitudes and behavior, in educational and professional aspirations, in conversational codes, even in their reading matter - than at any previous point in history. ${ }^{70}$ This was particularly true in enlightened intellectual circles where female participation in "rational discourse" was a point of pride. Historians of Enlightenment Britain have drawn attention to the near-absence of women from key sites of learning and debate: academies, political associations, taverns, coffeehouses. But against this must be set women's active presence in networks of enlightened sociability, like those of Edinburgh Whig society (where the leading topics of female conversation, according to one hostile observer, were the "Resumption of Cash-payments, Borough Reform, and the Corn-Bill"); or the bluestocking salons of London and similar literary coteries in provincial centers of Enlightenment like Lichfield (Dr. Johnson's home village in the Midlands, where the poet and critic Anna Seward reigned over a lively circle of intellectual iconoclasts that 
included Erasmus Darwin and Richard Edgeworth); or the high-minded, politicized world of Rational Dissent where feminists of both sexes found ready support. ${ }^{71}$ But it was among literary professionals that sexual barriers were weakest, as the exploding market for popular literature turned women into scribblers at such a rate that by the mid-eighteenth century their presence in some genres, especially novelwriting, threatened to eclipse that of men. "Amazons of the pen" were everywhere "contest [ing] the usurpations of virility" Samuel Johnson warned with nervous jocosity in $1753 .^{72}$

Surveying these developments, enthusiasts declared it women's "golden age." But plenty of opinion-makers were far from enthusiastic, decrying this reversal of the natural order and calling on men to reassert their God-given dominance over the fairer but inferior sex. For men of enlightened views, the dilemma was plain: how to promote female excellence as a standard of modern civility while holding the line against "Amazonianism," especially against the pretensions and successes of literary women? ${ }^{73}$ How to encourage the spread of Enlightenment values while keeping at bay Enlightenment Woman, the freethinking, independent femme philosophe? "Since ladies have had to do out of their chambers ... philosophy has gone to wreck," Lord Shaftesbury wailed in chorus with scores of like-minded defenders of male privilege, "and there has been sad havoc among the men of sense." ${ }^{\text {"74 }}$ Responding to this "havoc," enlightened gallants purveyed sentimentalized images of women that, regarded from this vantage point, do indeed appear - as Wollstonecraft denominated them - archaic. Repudiating traditional misogynist stereotypes of women as weak, superficial, emotionally incontinent, what gallant moralists offered in their stead were not realistic images of femininity but idealized inversions of these defamatory portrayals: feminine foibles sentimentalized into sex-specific virtues in a rearguard effort to stave off the equalizing pressures of commercial society, to shore up a "sexual distinction" that, natural or not, was clearly in need of some vigorous reinforcing. ${ }^{75}$ It was fear of "having women declared their equals" that prompted men's endless panegyrics to women, Wollstonecraft's friend and fellow feminist Mary Hays insisted:

Then it is that we hear of the heavenly softness of the sex, that with a glance can disarm authority and dispel rage. Then it is that we hear them tell, with as much earnestness and gravity as if it were true, or even possible, consistently with human nature; that in woman's weakness consists her strength, and in her dependence her power ... [and] that upon the whole, what women lose of power in an acknowledged way ... they make up for in the private scenes of life, etc, etc, etc.

"Unmeaning, impotent, romantic ravings ... [that] have not a leg to stand upon" was Hays's fierce concluding verdict on this sweet-talk, "when examined upon the principles of reason and commonsense." ${ }^{.76}$

If one were looking for a flashpoint in British feminism's relationship to Enlightenment, this would seem a good candidate. From the moment when en-

Feminists Versus Gallants: Manners and Morals in Enlightenment Britain 
lightened-gallant propaganda began appearing in Britain, it came under fire from sexual egalitarians. "For what are all these fine Speeches and Submissions," Mary Astell demanded, "but abusing [us] in a well-bred way?"77 Many midcentury literary women echoed her sentiments. ${ }^{78}$ But it was with the publication of the Rights of Woman, and the new alignments this created, that the issue became polarized between feminists and antifeminists, with women like Hays and Mary Robinson, another of Wollstonecraft's feminist intimates, lining up with Wollstonecraft against the "philosophical sensualists," while defenders of gallantry attacked her "de-sexing" extremism. ${ }^{79}$ This wider controversy, and the ripples rolling out from it into the nineteenth-century Woman Question, are beyond the remit of this essay, but they represented a significant element in Wollstonecraft's legacy to later feminist generations.

From the moment Wollstonecraft set foot in the political arena, she inveighed against politeness, that "Gothic affability" that cloaked inequalities in phony sentiment. ${ }^{80}$ Turning to that other great enemy of politeness, Rousseau, she endorsed his view of modern manners as "vile" and "corrupting," and, echoing his "admirable" Discourse on the Origin ... of Inequality, insisted that true civility could only exist among equals. ${ }^{81}$ In fact without equality "there can be no society; - giving a manly meaning to the term," she declared, since without equality there could be no genuine community of interests among individuals but only oppression, powermongering, and conflict. ${ }^{82}$ Continuing inequalities of wealth and rank make civilization in its proper sense - that is, "that state of [social] perfection necessary to secure the sacred rights of every human creature"-impossible. "For all the advantages of civilisation cannot be felt, unless it pervade the whole mass, humanising every description of men - and then it is the first of blessings, the true perfection of man." 83

This was a long way from the viewpoint of a David Hume or an Adam Smith. When critics charged Wollstonecraft with wanting "to bring all to the most perfect equality, and, by establishing absolute democracy, annihilate every species of subordination," they were pointing to a level of radical aspiration that placed her well to the left of most British enlighteners. ${ }^{84}$ It was this ultraradicalism that lent her attack on gallantry its sharp political edge. For if politeness were a corrupt social idiom, the lingua franca of "false civilisation," then gallantry was politeness's nastiest manifestation, substituting "insolent condescension" for true respect and fellowfeeling. It was from this perspective that Wollstonecraft called on all "reasonable men" to eschew gallantry in favor of egalitarian camaraderie:

Those writers are particularly useful, in my opinion, who make man feel for man, independent of the station he fills, or the drapery of factitious sentiments. I then would fain convince reasonable men of the importance of some of my remarks.... I appeal to their 
understandings; and, as a fellow-creature, claim, in the name of my sex, some interest in their hearts. I entreat them to assist to emancipate their companion, to make her a help meet for them $!^{85}$

Describing Wollstonecraft's attack on gallantry in his 1798 Memoirs of the Author of a Vindication of the Rights of Woman, William Godwin recalled how disconcerting its readers had found it, not least because of its rebarbative tone. The "spirited and decisive" way that Wollstonecraft set about her adversaries had "shocked the majority," he claimed. ${ }^{86}$ And indeed Wollstonecraft's savagery, as she dismembers the gallant position, is rather shocking. Declaring her intention to "severely" expose "those writers [who] insidiously degrade the sex while they are prostrate before their personal charms," she tears into Fordyce, Gregory, et al., with no trace of ladylike decorum, sneering at their "mellifluous" style (especially Fordyce's) and charging them with rank hypocrisy, a "libidinous mockery" of the sex they claim to admire. ${ }^{87}$ She quotes a satirical passage from Hume, comparing French gallantry to an Athenian saturnalia, a festival where masters served slaves in a ritual inversion of chatteldom. It's a very good analogy for her purposes, presenting chivalry as a carnivalesque transposition of gender-power relations. Hume's point in drawing the comparison - to distinguish good British gallantry from the bad French variety - is swept aside as she damns tout court the "specious homage" men offer to women "when, in fact, they are insultingly supporting their own superiority." 88 If this is French manners, then British gallants are true Frenchmen, she implies. "It is vain to expect much public or private virtue, till both men and women . . treat each other with respect. . . . I mean . . . the modest respect of humanity, and fellowfeeling, not the libidinous mockery of gallantry." 89

As always in the Rights of Woman, the polemic is directed as much at women as at men, or at least at those women who, their minds and morals deformed by "mutable prejudices," "adopt the sentiments that brutalise them, with all the pertinacity of ignorance." 90 The accusation of female collusion, central to her case, is spelled out unflinchingly:

Exalted by their inferiority (this sounds like a contradiction), they constantly demand homage as women, though experience should teach them that the men who pride themselves upon paying this arbitrary insolent respect to the sex, with the most scrupulous exactness, are most inclined to tyrannise over, and despise, the very weakness they cherish. ${ }^{91}$

The "passions of men" have "placed women on thrones," she writes, from which they preside like caged songbirds "stalk[ing] with mock majesty from perch to perch." Caressed and spoiled, such women luxuriate in their sexual reign, but "health, liberty and virtue are given in exchange." "Ah!" she sighs with profound exasperation, why do women permit themselves to be thus "deluded by hollow respect, till they are led to resign . . . their natural prerogatives?",92

The condemnation is harsh — so harsh that Wollstonecraft has sometimes been 
described as misogynistic. Why is she so tough on feminine susceptibilities? The answer lies partly in the anti-elitist thrust of her argument, her condemnation of gallantry as courtly licentiousness, the charge that middle-class gallants and coquettes are merely aping "the great." Woman as portrayed in the Rights of Woman is sister to the emblematic "lady of fashion," favorite target of all eighteenth-century bourgeois philippics against elite luxury and lasciviousness. ${ }^{93}$ Giving this figure a radical spin, Wollstonecraft denounces her as an emblem not just of aristocratic vice but of "false civilisation" in general, of commercial modernity and its arriviste social codes. But more than this, this benighted Woman, this flattered, deluded coquette, is also - and here is where she becomes a feminist instrument - an exposé of the enlightened-gallant female ideal, the "fair sex" as seen in the steely light of feminist reason. Viewing gallantry's model woman without her rhetorical fig leaf, what Wollstonecraft finds is a sexualized monolith, a figure stripped of everything but her physical charms and "negative virtues": "patience, docility, good-humour, and flexibility, virtues incompatible with any vigorous exertion of intellect.".94 "All women are ... levelled, by meekness and docility, into one character of yielding softness and gentle compliance." 95 Like "artificial politeness" in general, which enforces the very divisions of rank and power that its ritual obsequies are meant to obviate, gallantry imposes on women a "sexual distinction" that is as fake as it is destructive, displacing female human beings with eroticized "fair creatures," "lovely goddesses," "angels" - "chimeras" of the male imagination, as Wollstonecraft summarily dismisses such images. "Why are girls to be told that they resemble angels," she demands

but to sink them below women? ... Yet they are told, at the same time, that they are only like angels when they are young and beautiful; consequently, it is their persons, not their virtues, that procure them this homage. . . . happy would it be for women, if they were only flattered by the men who loved them; I mean, who love the individual, not the sex. ${ }^{96}$

As objects of male fantasy and desire, women are "the sex," with every aspect of their lives invested with erotic meaning - even the charming postures they adopt when praying, according to James Fordyce. "She was quite feminine, according to the masculine acceptation of the word," Wollstonecraft writes of one woman who was so captivated by male attentions that the "wife, mother, and human creature [were] ... all swallowed up" in the coquette. ${ }^{97}$ It's a hyperbolic, surreal imagebut then so is the one to which it responds. Both are polemical constructs fashioned at the cutting edge of Enlightenment opinion, at the point where it splintered between a refashioned, polite male supremacism and a feminist vision of womanhood unencumbered by "feminalities," to use a phrase current among prowoman writers of the day - a "wild wish," as Wollstonecraft put it, to "see the distinction of sex confounded," and women free to pursue virtue and truth on terms equal to those of men. 
Dismissing then those pretty feminine phrases, which the men condescendingly use to soften our slavish dependence, and despising that weak elegancy of mind, exquisite sensibility, and sweet docility of manners, supposed to be the sexual characteristics of the weaker vessel, I wish to show that elegance is inferior to virtue, [and] that the first object of laudable ambition is to obtain a character as a human being, regardless of the distinction of sex..$^{98}$

For Enlightenment to triumph, women too must become enlightened, abandoning false femininity for the "practical virtues" of rationality, independence, selfreliance: merits that Wollstonecraft sometimes labels - to the dismay of presentday readers - as "manly," an adjective that in the eighteenth century, when manliness was virtually synonymous with personal strength, had more universal application than it does today. It would be naive to suggest that such language carried no male bias (recognizing this, in the Rights of Woman Wollstonecraft deliberately amended her earlier description of the republican historian Catherine Macaulay as a "masculine writer," saying that she would no longer "admit of such an arrogant assumption of reason" by men). ${ }^{99}$ But the real significance of these prescriptions lay in their refusal of sexual divisions, their drive toward an impolite world where men and women would coexist as equals. Describing her own conversations with men, Wollstonecraft boasted about their frankness, including on sexual topics:

I have conversed, as man to man, with medical men, on anatomical subjects; and compared the proportions of the human body with artists ... yet ... was never reminded by word or look of my sex ... And I am persuaded that in the pursuit of knowledge women would never be insulted by sensible men ... if they did not by mock modesty remind them that they were women. ${ }^{100}$

The claim, given the attitudes of the time, may seem overoptimistic. But the circle of radical intellectuals to which Wollstonecraft belonged regularly infringed gender norms. An intensely sociable band, in the early 1790s these men and women met frequently for dinner, often at the home of Wollstonecraft's publisher, Joseph Johnson, where they would remain talking and arguing (the poet Anna Barbauld later recalled) long into the night. ${ }^{101}$ From the fragmentary evidence we have of these occasions, women seem to have participated in them on an equal basis. Certainly Wollstonecraft did: encountering her for the first time over Johnson's table in November 1791, Godwin soon found himself embroiled in a fierce dispute over religion that lasted the entire meal. ${ }^{102}$ Later, traveling in Scandinavia, Wollstonecraft enjoyed startling men she met there by quizzing them on political and economic issues ("men's questions," as one Danish naval man described her interrogations). ${ }^{103}$ "We indulged little in common society chitchat," the writer Helen Maria Williams wrote of the little Paris community of radical Britons to which she and Wollstonecraft belonged in the early 1790s, "The women seemed to forget concern to please, and the men thought less about admiring them. ... In that salon there 
was something better than gallantry. What appeared most were mutual esteem and a shared interest in the great issues of the day." ${ }^{104}$ Thus, whereas among the bon ton "decorum is to supplant nature, and banish all simplicity," in Wollstonecraft's world it was open-handed sincerity - "the simplicity and generosity of republican manners," as one man eulogized them - that earned social kudos. ${ }^{105}$ What all this really amounted to was a particularly uncompromising version of the Enlightenment ethos. While literary gallants hymned feminine propriety and bleated about the perils of over-enlightened Amazons, among British radicals camaraderie of equals became the keynote of an enlightened sexual etiquette. ${ }^{106}$

"Vigorous minds," Mary Hays wrote of Wollstonecraft, "are with difficulty restrained within the trammels of authority; a spirit of enterprise, a passion for experiment ... urges them to quit beaten paths ... to burst the fetters of prescription." ${ }^{\prime 107}$ As a reminder of what Enlightenment could mean to a woman - and what enlightened gallants feared it would mean - this cannot be bettered. And it reminds us of Wollstonecraft's importance not just as a feminist polemicist but as an incarnation of dissident womanhood, the Learned Lady turned Jacobin subversive. When Hays wrote these words, a few months after Wollstonecraft's death in September 1797, Wollstonecraft's reputation stood high among progressive-minded Britons. Even the repression blighting British politics after 1793 had not diminished her standing. But very soon this changed. The publication of Godwin's Memoirs, with its unblushing account of her outré sexual history, unleashed a torrent of right-wing abuse, transforming her from a respected philosophe into an emblem of revolutionary depravity, a "philosophical wanton," a "hyena in petticoats." Feminism, always at the radical edge of liberal opinion, was driven beyond its borders, into the wilder territory of left-wing Unitarianism, utopian socialism, and plebeian democracy, where it was to remain for the next half century. Opinion-makers of both sexes who had once applauded the "champion of female equality" now spurned her. ${ }^{108}$ As the age of Enlightenment drew to a close, a ragbag of antifeminist ideas - evangelical renovations of Pauline doctrine, quasi-scientific arguments for female inferiority, political defences of male prerogative - attached themselves to the remnants of enlightened gallantry to generate that unwholesome blend of myth and prejudice that was to become Victorian sexual ideology. The feminist protest against femininity, against the "factitious character" foisted on women by new-wave defenders of male privilege, was silenced for a time, as dogmas of Women's Place took center-stage, pushing the women's-rights banner into the dust. ${ }^{109}$

What then was the true Enlightenment legacy: the antifeminist dogmas that acquired such influence in the years following Wollstonecraft's death, or the opposition to them that appeared nearly a century later, in the late-nineteenth/earlytwentieth-century women's movement? The answer of course is both, as with the rise of a mass feminist politics the contest between sexual egalitarians and polite male supremacists waged in the 1790s, and pushed to the sidelines of political life 
after 1798, found its next point of engagement. Gallantry, always a fragile contrivance, acquired a host of vociferous new opponents who, stripping away its unctuous rhetoric to expose its brutality - its "sentimental and savage" view of women, to quote the suffragette Cicely Hamilton — pushed it closer to oblivion. ${ }^{110}$ When in 1792 Wollstonecraft called for a feminist Enlightenment, British femmes philosophes - tiny in number, socially disadvantaged, politically marginal - were in no position to realize this ambition. Several generations later, with women hammering at the doors of Parliament, the prospects looked better, and better still at the beginning of the third millennium. Historians worry that Enlightenment, once the monopoly of an Olympiad of male philosophers, has become too broad, too imprecise to retain any historical meaning. But if we think of Enlightenment not as a single historical entity, which it clearly was not, but as a constellation of aspirations evolving and democratizing over time, under the pressure of incoming intellectual constituencies, then its real historic significance becomes evident. The triumph of truth over prejudice, liberty over despotism, meant something different when demanded by women rather than by men, something more subversive of quotidian realities, and it was this difference that divided feminists from their Enlightened opponents. The difference remains: two centuries after the Rights of Woman, Western women still need an equal-rights Enlightenment. Perhaps Mary Wollstonecraft's twenty-first century daughters will finally inaugurate it.

\section{Notes}

Thanks to Michèle Cohen, Sarah Knott, Mary Catherine Moran, Karen O’Brien, Jane Rendall, and the editors of Representations for helpful comments on this essay. Thanks also to Cora Kaplan, organizer of the conference "Women's Writing in Britain, 1660-1830" (Chawton House Centre for Early English Women's Writing) for which the essay was originally written.

1. David Hume, "Of the Rise and Progress of the Arts and Sciences," in Essays: Moral, Political and Literary (1741-52; Indianapolis, 1985), 133.

2. William Godwin, Memoirs of the Author of a Vindication of the Rights of Woman (1798; Harmondsworth, 1987), 231.

3. Mary Wollstonecraft, An Historical and Moral View of the Origin and Progress of the French Revolution (1794; hereafter French Revolution), in M. Butler and J. Todd, eds., The Works of Mary Wollstonecraft (hereafter Works), 7 vols. (London, 1989), 6:6-7.

4. Eric Hobsbawm, On History (1997; London, 1998), 336.

5. For negative evaluations of Wollstonecraft as an Enlightenment thinker see, inter alia, Timothy J. Reiss, "Revolution in Bounds: Wollstonecraft, Women, and Reason," in L. Kauffman, ed., Gender and Theory (Oxford, 1989); Moira Gatens, " "The Oppressed State of My Sex': Wollstonecraft on Reason, Feeling, and Equality,” in M. L. Shanley and C. Pateman, Feminist Interpretations and Political Theory (Cambridge, 1991), 6-128. For more positive accounts, see Pauline Johnson, "Feminism and the Enlightenment," Radical Philosophy 63 (1993); Roy Porter, Enlightenment: Britain and the Creation of the 
Modern World(London, 2000); Kate Soper, "Naked Human Nature and the Draperies of Custom," in Eileen Yeo, ed., Mary Wollstonecraft and 200 Years of Feminism (London, 1997), 207-21.

6. Mary Wollstonecraft, A Vindication of the Rights of Woman (1792; Cambridge, 1995), 74 (hereafter $V R W$ ).

7. For the complexities of Enlightenment ideas about gender, see Sarah Knott and Barbara Taylor, eds., Women, Gender, and Enlightenment (New York, forthcoming). For a brief but illuminating discussion of the issues, see also Dorinda Outram, The Enlightenment (Cambridge, 1995).

8. Mary Hays, quoted in William St. Clair, The Godwins and the Shelleys: The Biography of a Family (London, 1989), 146.

9. Wollstonecraft, French Revolution, 15-23, 7.

10. Mary Wollstonecraft, A Vindication of the Rights of Men (1790; Cambridge, 1995), 64 (hereafter $V R M)$.

11. Mary Wollstonecraft, The Wrongs of Woman, or Maria (1798), in Works, 1:115-16.

12. Wollstonecraft, $V R W, 90$.

13. Ibid., $178 . \quad$ 14. Ibid., 74. 15. Ibid., 175.

16. For this, see Mary Catherine Moran, "Between the Savage and the Civil: Dr John Gregory's Natural History of Femininity," in Knott and Taylor, Women, Gender, and Enlightenment.

17. See my Mary Wollstonecraft and the Feminist Imagination (Cambridge, 2003), 98-110, for a discussion of the prowoman dimension of British Protestantism.

18. Moran, "Between the Savage and the Civil." In VRW, Wollstonecraft is much gentler in her handling of John Gregory than of James Fordyce, acknowledging with "affectionate respect" the "paternal solicitude" that pervades Gregory's Legacy while insisting that she cannot "speciously support" his bad opinions (178). And indeed Gregory's conduct toward his daughters - he ensured that they had sufficient income to live as independent spinsters, if they chose - would certainly have won her approval.

19. Edmund Burke, Reflections on the Revolution in France (1790; Indianapolis, 1987) 67.

20. Wollstonecraft, VRM, 25.

21. Wollstonecraft, $V R W, 179$.

22. John Dwyer, The Age of the Passions: An Interpretation of Adam Smith and Scottish Enlightenment Culture (East Linton, Scotland, 1999), 127.

23. Dena Goodman, The Republic of Letters: A Cultural History of the French Enlightenment (Ithaca, N.Y., 1994), chap. 2.

24. Lawrence E. Klein, "Gender, Conversation, and the Public Sphere in Early Eighteenth-Century England," in J. Still and M. Worton, eds., Textuality and Sexuality: Reading Theories and Practices (Manchester, 1993), 106; [Judith Drake?], An Essay in Defence of the Female Sex, 4th ed. (London, 1721), 130.

25. The Spectator, ed. Gregory Smith, 4 vols. (London, 1958-1961, 1956), 1:33, 9.

26. Anthony A. Cooper, Earl of Shaftesbury, Characteristics of Men, Manners, Opinions, Times (1711; Cambridge, 1999), 237.

27. Ibid., 233.

28. Hume, "Arts and Sciences," 131. The focus on chivalry was not confined to Scottish Enlightenment writings but was also to be found in literary criticism: e.g., Thomas Warton, A History of English Poetry (1774-1781); Richard Hurd, Letters on Chivalry and Romance (1762); Thomas Percy, Reliques of Ancient English Poetry (1765). On this, see Lionel Gossman, Medievalism and the Ideologies of the Enlightenment (Baltimore, 1968).

29. John Millar, The Origin of the Distinction of Ranks (London, 1779), 78-79. 
30. While virtually all Scottish historians concerned themselves with the impact of the civilizing process on women, their views on the matter were complex and diverse. For this see Silvia Sebastiani, "'Races': Women and Progress in the Scottish Enlightenment," in Knott and Taylor, Women, Gender, and Enlightenment; and also Sylvana Tomaselli, "The Enlightenment Debate on Women," History Workshop Journal 20 (1985): 101-24; J. Rendall, introduction to W. Alexander, History of Women, reprint of the 3rd ed. (Bath, 1994); J. Rendall, “Tacitus Engendered: 'Gothic Feminism' and British Histories, c. 1750-1800,” in G. Cubitt, ed., Imagining Nations (Manchester, U. K., 1998) 57-74.

31. A Clergyman of the Church of England [John Bennett], Strictures on Female Education (London, 1787), 33-34.

32. Shaftesbury correspondence; quoted in Brian Cowan, "Reasonable Ecstasies: Shaftesbury and the Languages of Libertinism," Fournal of British Studies 37 (April 1998): 118.

33. James Fordyce, The Character and Conduct of the Female Sex, 2nd ed. (London, 1776), 7-8.

34. Millar, Origin of Ranks, 89.

35. Siep Stuurman, François Poulain de la Barre and the Invention of Modern Equality (Cambridge, Mass., 2004).

36. William Alexander, The History of Women (London, 1779), 2:41, 36.

37. Alexander Jardine, Letters from Barbary, France, Spain, Portugal (London, 1788), 1:320.

38. David Hume, A Treatise of Human Nature (1739-40; Harmondsworth, 1987), 620-24. Pinning down what Enlightenment theorists mean by "female nature" is difficult, not least because - as Mary Catherine Moran pointed out to me in a personal communication- "nature" and "natural" had two meanings in Enlightenment narratives of civilization: "in terms of innate characteristics, or a 'scientistic' notion of nature as that which pertains to the physical/material world in the absence of intervention, their comparative/ historical perspective did tend to undermine the 'naturalness' of certain feminine traits. But they also used 'nature' to refer to that which is fitting and appropriate in a manner that did allow for human intervention/human history. Thus Hume on justice (and on female chastity): justice/chastity are artificial and conventional in the sense that there is no innate sense of justice/chastity; these virtues are rather the product of complex social/historical interactions. But he allowed that they were 'natural' in a secondary sense, ie, that their historical evolution was entirely in accordance with those other virtues which were natural in a primary sense. What makes these authors hard to pin down is that they move from one meaning to another as it suits their purposes."

39. Alexander, History (1779), 40.

40. Fordyce, Character of Female Sex, 24.

41. [Bennett], Female Education, 21-22.

42. David Hume, "Of Refinement in the Arts" (1748), in Essays, 271.

43. Hume, "Arts and Sciences," 134.

44. Fordyce, Character of Female Sex, 88.

45. For opposition to Lord Chesterfield, see Philip Carter, Men and the Emergence of Polite Society in Britain, 1660-1800 (Harlow, 2001), 78-80, 128-129; Michèle Cohen, Fashioning Masculinity: National Identity and Language in the Eighteenth Century (London, 1996), 43-46.

46. Smith, Spectator, 3:191. In an unpublished paper, Michèle Cohen makes a related argument, tracing a shift from politeness to chivalry in the late eighteenth century: I am grateful to her for sharing these ideas with me.

47. Hume, "Refinement in the Arts," 271.

Feminists Versus Gallants: Manners and Morals in Enlightenment Britain 
48. Millar, Origins of Ranks, 101-3.

49. Hume, "Arts and Sciences," 131-33.

50. David Fordyce, Dialogues Concerning Education (London, 1760), 87. For an illuminating discussion of this work, see Cohen, Fashioning Masculinity, 46-50.

51. Ibid., 84.

52. Ibid., 45, 46, 89, 92, 81 .

53. Ibid., 150, 47, 111, 118, 5.

54. [Bennett], Female Education, 50-52.

55. Ibid., 123.

56. Vicesimus Knox, Essays, Moral and Literary (London, 1779), 2:362.

57. Fordyce, Character of Female Sex, 83.

58. Fordyce, Dialogues, 107.

59. Ibid., 90.

60. Jardine, Letters from Barbary, 1:323.

61. David Hume, An Enquiry Concerning the Principles of Morals (1751; New York, 1969), 221.

62. Moran, "Between the Savage and the Civil."

63. Amanda Vickery, The Gentleman's Daughter: Women's Lives in Georgian England (London, 1998), 217. See also Carter, Men and Polite Society, chap. 4; G.J. Barker-Benfield, The Culture of Sensibility: Sex and Society in Eighteenth-Century Britain (Chicago, 1992), chap. 3.

64. Adam Smith, The Theory of Moral Sentiments (1759; Indianapolis, 1982), 209.

65. J. G. A. Pocock, Virtue, Commerce, and History (Cambridge, 1985), 114-18; Carol Kay, "Canon, Ideology, and Gender: Mary Wollstonecraft's Critique of Adam Smith," New Political Science 15 (1986); Terry Eagleton, The Ideology of the Aesthetic (Oxford, 1990). See also John Mullan, Sentiment and Sociability: The Language of Feeling in the Eighteenth Century (Oxford, 1988).

66. Pocock, Virtue, 115.

67. Alexander, History (1779), 1:325.

68. Linda Colley, Britons: Forging the Nation, 1707-1837(London, 1992), 250. See Vickery, Gentleman's Daughter; Margaret Hunt, The Middling Sort: Commerce, Gender, and the Family in England, 1680-1780 (Berkeley, 1996); Olwen Hufton, The Prospect Before Her: A History of Women in Western Europe (London, 1995).

69. Dror Wahrman, "Percy's Prologue: From Gender Play to Gender Panic in Eighteenth Century England," Past and Present 159 (May 1998):113-60.

70. For this, see Hunt, Middling Sort, 166-71; Vickery, Gentleman's Daughter, 1-12; John Brewer, The Pleasures of the Imagination: English Culture in the Eighteenth Century (London, 1997), 76-83.

71. Jane Rendall, “'Women that would plague me with rational conversation': Aspiring Women and Scottish Whigs, c 1790-1830," in Knott and Taylor, Women, Gender, and Enlightenment. Rendall discusses in detail the controversies aroused by women's involvement in Edinburgh Whig society.

72. Samuel Johnson, The Adventurer 115, Dec. 1753, in Works (London, 1958), 2:458. For the growth of female authorship in eighteenth-century Britain see, inter alia, Cheryl Turner, Living by the Pen: Women Writers in the Eighteenth Century (London, 1992); Catherine Gallagher, Nobody's Story: The Vanishing Acts of Women Writers in the Marketplace, 1670-1820 (Berkeley, 1994); Norma Clarke, The Rise and Fall of the Woman of Letters (London, 2004).

73. For "Amazonian" as an eighteenth-century "code word for female pride and gender crossing," see Barker-Benfield, Culture of Sensibility, 351-52, 377-80. 
74. Shaftesbury correspondence, quoted in Cowan, "Reasonable Ecstasies," 118.

75. For an alternative view, emphasizing the strong support some British literary men gave to female authorship, see Arianne Chernock, "Champions of the Fair Sex: Men and the Creation of Modern British Feminism" (PhD diss., University of California, Berkeley, 2004). Chernock's excellent thesis focuses on the minority feminist tendency of British Enlightenment.

76. Mary Hays, Appeal to the Men of Great Britain in Behalf of Women (London, 1798), 116-17.

77. Mary Astell, "Reflections Upon Marriage" (1700), in The First English Feminist, Reflections Upon Marriage and Other Writings by Mary Astell, ed. Bridget Hill (New York, 1986), 100.

78. Laura Runge, "Beauty and Gallantry: A Model of Polite Conversation Revisited," Eighteenth-Century Life 25 (2001): 43-63. Karen O'Brien points out, however, that in the later part of the eighteenth century the word "chivalry," unlike "gallantry," elicited a positive response from some literary women, including Elizabeth Montagu, Clara Reeve, and Hannah More, who saw it as "embed[ding] respect for women within a wider system of morality, public responsibility and philanthropy." Wollstonecraft's cynicism about such usages was later echoed by John Stuart Mill, who in 1826 dismissed chivalry as "nine tenths" gallantry, and argued that such "fopperies" indicated no real "solicitude for [women's] welfare"; Karen O'Brien, "Introduction: Sexual Distinctions and Prescriptions," in Knott and Taylor, Women, Gender, and Enlightenment.

79. Anne Frances Randall [Mary Robinson], A Letter to the Women of England on the Injustice of Mental Subordination (London, 1799), 1.

80. Wollstonecraft, VRM, 16.

81. Wollstonecraft, French Revolution, 61.

82. Wollstonecraft, VRM, 39.

83. Wollstonecraft, French Revolution, 183, 220.

84. General Magazine and Impartial Review 4 (1791): 26.

85. Wollstonecraft, VRW, 240.

86. Godwin, Memoirs, 231.

87. Wollstonecraft, VRW, 173-78, 211.

88. Ibid., 132.

91. Ibid., $130 . \quad 92$. Ibid., 130.

90. Ibid., 184.

93. For a discussion of this, see Taylor, Mary Wollstonecraft, introduction and chaps. 5 and 7.

94. Wollstonecraft, VRW, 133.

95. Ibid., 177. 96. Ibid., 176. 97. Ibid., 269.

98. Ibid., $76-77$.

99. Wollstonecraft, $V R W, 188$.

100. Ibid., 209.

101. Gerald P. Tyson, Joseph Fohnson: A Liberal Publisher (Iowa City, 1979), 118.

102. Godwin, Memoirs, 235-36.

103. Mary Wollstonecraft, Letters Written during a Short Residence in Sweden, Norway and Denmark (1796), in Works, 6:248.

104. Quoted in Gary Kelly, Revolutionary Feminism: The Mind and Career of Mary Wollstoncraft (Basingstoke, U. K., 1992), 147.

105. George Dyer, letter to Mary Hays, n.d., in A. F. Wedd, The Love Letters of Mary Hays (London, 1925), 238.

106. Recalling good times spent at Joseph Johnson's home, Anna Barbauld described her fellow radical literati as "a chosen knot of lettered equals"; Anne Janowitz, "Amiable

Feminists Versus Gallants: Manners and Morals in Enlightenment Britain 
and Radical Sociability: Anna Barbauld's 'Free Familiar Conversation,', ' in G. Russell and C. Tuite, eds, Romantic Sociability: Social Networks and Literary Culture in Britain, 1770-1840 (Cambridge, 2002), 71.

107. Mary Hays, "Memoirs of Mary Wollstonecraft," in The Annual Necrology, 1797-1798 (London, 1800), 411.

108. For a discussion of this, see Taylor, Wollstonecraft, epilogue.

109. The image of Wollstonecraft's banner in the dust comes from William Thompson, Appeal of One-Half the Human Race, Women, Against the Pretensions of the Other Half, Men, to Retain Them in Political and Thence in Civil and Domestic Slavery (1825; London, 1983), xxiii.

110. Cicely Hamilton, Marriage as a Trade (1909; London, 1981), 23. 